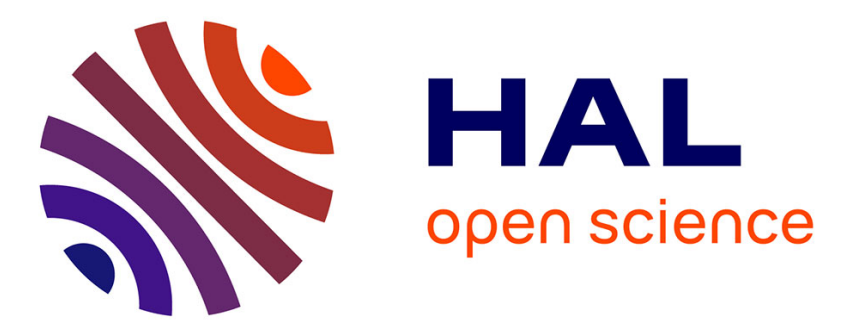

\title{
Top-down/bottom-up approach for developing sustainable development indicators for mining: Application to the Arlit uranium mines (Niger)
}

Aurélie Chamaret, Martin O’Connor, Gilles Récoché

\section{- To cite this version:}

Aurélie Chamaret, Martin O'Connor, Gilles Récoché. Top-down/bottom-up approach for developing sustainable development indicators for mining: Application to the Arlit uranium mines (Niger).

International Journal of Sustainable Development, 2007, 10 (1/2), pp.161-174. hal-00194505

\section{HAL Id: hal-00194505 \\ https://hal.science/hal-00194505}

Submitted on 6 Dec 2007

HAL is a multi-disciplinary open access archive for the deposit and dissemination of scientific research documents, whether they are published or not. The documents may come from teaching and research institutions in France or abroad, or from public or private research centers.
L'archive ouverte pluridisciplinaire HAL, est destinée au dépôt et à la diffusion de documents scientifiques de niveau recherche, publiés ou non, émanant des établissements d'enseignement et de recherche français ou étrangers, des laboratoires publics ou privés. 


\title{
TOP-DOWN/BOTTOM-UP APPROACH FOR DEVELOPING SUSTAINABLE DEVELOPMENT INDICATORS FOR MINING:
}

\section{APPLICATION TO THE ARLIT URANIUM MINES (NIGER)}

\author{
A. Chamaret ${ }^{a(b)}$, M. O’Connor $^{a)}$ and G. Récoché ${ }^{b)}$ \\ a) Université de Versailles Saint Quentin en Yvelines, Centre d'Economie et d'Ethique pour \\ l'Environnement et le Développement - 47, bld Vauban - 78047 Guyancourt Cedex, France \\ b) BRGM, Services Ressources Minérales - 3, av. C. Guillemin - BP 6009- 45060 Orléans, France \\ Contact: a.chamaret@brgm.fr
}

\begin{abstract}
Minerals extraction is related to complex sustainable-development issues that are subject to international and local controversies. Debates and decisions need to be based on objective and comparative elements. Defining strong indicators for assessing impacts and performances of mining sites thus appears necessary to inform and support the decision-making process for stakeholders. In recent years, many indicator sets have been developed on an international level based on top-down approaches. But they commonly lack legitimacy for stakeholders and adequacy to specific site issues. They thus need to be complemented by the consultation of local actors concerned by such mining activity, in order to define indicators that are closer to the needs and contexts of the specific sites. This is the goal of the work reported in this paper, undertaken at the Arlit uranium mines in Niger. Our objective was to define indicators that are understood and accepted by all actors, as a basis for robust and transparent assessment of the impacts and performances of mining sites across the four sustainable development dimensions, and at local, regional and national scales.
\end{abstract}

\section{Key words}

Deliberation, Evaluation, Indicators, Mining, Multi-criteria, Niger, Stakeholders, Stewardship, Sustainable development, Top-down/bottom-up, Uranium 


\section{Introduction}

Natural-resource exploitation is related to crucial sustainability issues. Mineral extraction is no exception; the mining activities can generate both positive and negative impacts on the concerned areas, from site to national levels, raising notably the problem of an (in)equitable distribution of costs and benefits across stakeholders. Debates have been raging for many decades within and around this sector, between commercial and industrial justifications [1], NGO pressures [2], and new rules imposed by international finance organizations [3]. Many arguments are still rooted in partisan visions, and the broad definition of sustainable development in the Bruntland report - i.e., "development that meets the needs of the present without compromising the ability of future generations to meet their own needs" - does not, in itself, provide a satisfactory basis for defining what is and is not sustainable in the mining sector. Moreover, mining sites now have to satisfy claims of local people in order to obtain their 'social' operating license.

It is thus clear that factual and comparative elements are likely to be helpful in order better to appreciate the mining sector's impact [4], to support decision makers in their strategic choices, to inform stakeholders, and to make the debate more objective (with clearly defined areas of 'common ground'). In past years much work has been done in this field, with two main objectives [5]: mining companies CSR reporting $[6,7,8]$ and measuring the sector's contribution to a country's sustainability $[9,10,11]$. There have been a number of general studies conducted on indicators for measuring the real impact of a mining site on a region or country [12,13]. Most of these studies are, however, intended for worldwide application, and have been developed by scientists, industrialists or NGO representatives aiming at 'generic' international perspectives. None of them is specific to Africa.

The research reported in this paper, carried out in collaboration between BRGM and UVSQ, aims at contributing in a 'bottom-up' way to this reflection. It has set out to define procedures and obtain robust indicators that are understood and accepted by all stakeholders and adapted to site specificities, permitting assess a mining site's impact and performance from local to national levels in Africa. Section 1 of the paper presents the theoretical and methodological underpinnings of the research work. Section 2 then summarises the empirical results drawn from application of this approach to the uranium mines of Arlit in Niger.

\section{The need for a double top-down/bottom-up approach}

The global scope of sustainable development issues leads to calls for indicators that are transferable, generic and scientifically valid, to provide relevant information and allow comparisons between entities (e.g. between mining sites, regions, states). However, such indicators, generally defined by 'experts' at high levels, can be lacking legitimacy in the eyes of stakeholders and do not always respond to the specific circumstances of a site.

It can easily be agreed that indicators are only relevant and useful if they fit the user's needs [14]. But, who are the users? Whose needs? A participatory (or 'bottom-up') approach answers to many of the 
needs for information and management tools of the actors implicated in the activity, and also can enhance the legitimacy of such indicators. Thus, expected benefits lie not only in the results, i.e. the indicators, but also in the means, i.e. the participatory process that increases the stakeholders' adhesion to results [15].

Furthermore, it is obvious that each mining site will present distinct features that invalidate the idea of a 'one-fits-all' indicator set. Such features include:

- Geographical location: the issues of a mining site located in a desert area (e.g. access to water) will differ from those of a mine in a forest area (deforestation); a mine close to a city will generate different impacts than one in an unpopulated area; issues of a mine in Africa will obviously differ from those of a European or Australian mine due to cultural differences.

- Infrastructure: a mining town will generate major perturbations in the traditional ways of living and building; a fly-in fly-out system generates more diffuse impacts, but less local economic benefits.

- Exploitation type: an open-pit mine involves questions linked to landscape preservation and an underground mine will raise issues related to future security of the site in terms of subsidence.

- Extracted substance: for example, uranium mining implies specific health issues linked to radiological impact; the mining of other metals such as copper, lead, zinc or gold, raises environmental issues related to acid leaching.

- Mine cycle phase: the building phase will not have the same impact (massive population movements) as production (raise of the standard of living, etc.), or post-mine (unemployment, staff conversion).

The challenges of legitimacy in the eyes of stakeholders and of major differences between mining sites, thus lead to the suggestion that indicators from international frameworks ought to be complemented by indicators that more directly answer to the issues of a specific site and its stakeholders. In combining international framework contributions and participative processes, we propose a top-down/bottom-up approach as a way to confront indicators that are scientifically valid and generic (top-down) with stakeholder needs on specific sites (bottom-up) [16].

\section{Application to the uranium mines of Arlit}

The uranium mines that have been the object of our empirical work are located at Arlit, in the desert region of Aïr in northern Niger. Two companies are exploiting the mines - the Société des Mines de I'Aïr (SOMAïR) for the open-pit mine and the Compagnie des Mines d'Akokan (COMINAK) for the underground mine - whose majority shareholders are the French company AREVA and the Nigerian state (ONAREM).

Initiated in the 1970's, the mining activity has contributed to national development programs in Niger, notably during the 1980's when uranium prices were high. But, whereas today Niger is the fourth 
largest uranium producer in the world with $12 \%$ of global production [17], it is nonetheless rated as one of the poorest performers in terms of the Human Development Index [18].

The objective of our study in Niger was to evaluate uranium mining's contributions to and impacts on the region and the country, with indicators that fit the stakeholders' needs and interests. As shown in Figure 1, our approach consists of four steps, enriched by both top-down and bottom-up elements. The following sub-sections provide more details about the work undertaken on site.

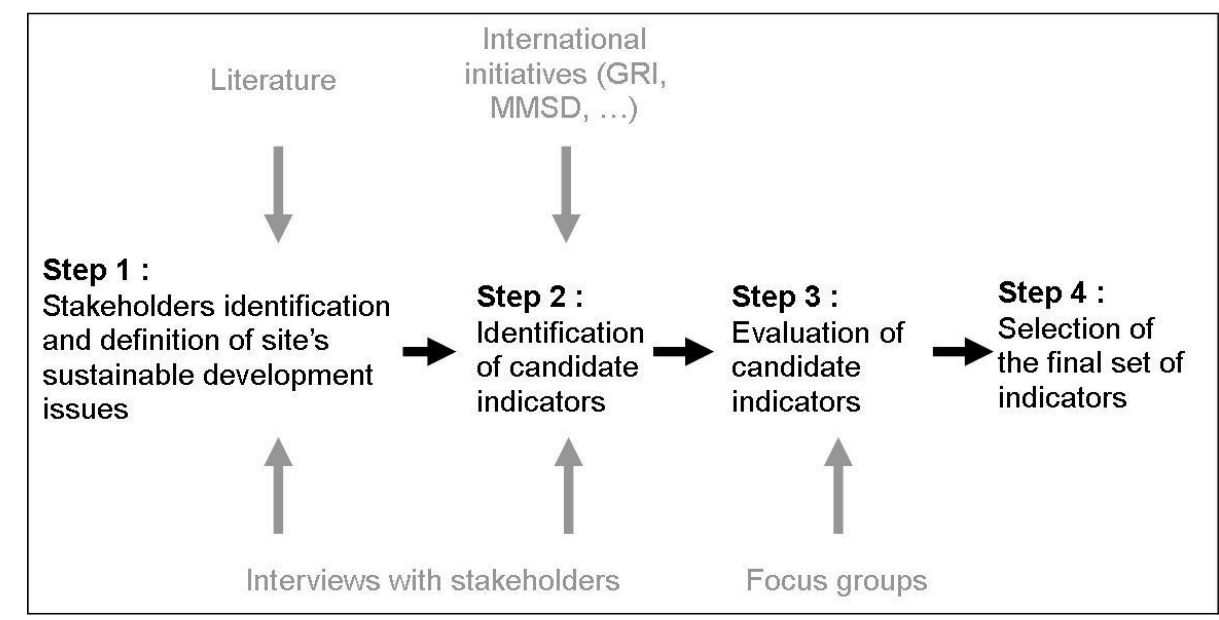

Figure 1 - The 4 steps of the process

\section{Step 1: Identifying stakeholders and defining sustainable development issues of the extraction} site

The objective of this first phase was to define and conceptualize the framework for a better understanding and analysis of issues. Several different elements had to be taken into account in this analysis: stakeholder identification, understanding of site issues and articulation of the different scales. This phase of constructing and structuring the evaluation 'problem' is of crucial importance for the whole process.

\section{Stakeholder identification}

The first point was to identify actors that are affected by the activity and, thereby, have to be implied in the process. Freeman [19] has defined stakeholders in a broad way as "any group or individual who can affect or is affected by the achievement of the organization's objectives". We based our identification on the typology proposed by Faucheux \& Nicolaï (2004) [15] and by O'Connor \& Spangenberg [16] that gives supplementary elements of analysis in separating four main stakeholder groups for firms:

- Internal stakeholders that have direct interests in companies: they include management, employees, unions, and shareholders.

- Traditional external stakeholders identified as the firm's partners, that all have a direct commercial importance for the company, such as suppliers, customers, banks, and insurers. 
- Enlarged external stakeholders, identified as dialogue partners that have an interest or requirements concerning the performances of a plant, a company or an industrial sector, and have a direct incidence on commercial success, such as local population, NGOs, associations, and partner firms.

- Coordinating authorities: government, local authorities, and professional associations.

Based on this typology, on several studies on mine stakeholders [20,21], and on local knowledge of Nigerian companies, a list of actors to engage in the process has been drawn up; 42 interviews were carried out in Niger, involving some 70 people (Table 1).

Table 1 - Repartition of stakeholders implied in the process

(Figures in brackets indicate the number of interviews with this stakeholder category)

\begin{tabular}{|c|c|c|}
\hline & LOCAL & NATIONAL \\
\hline Internal stakeholders & $\begin{array}{l}\text { Management (10) } \\
\text { Employees / Unions (3) }\end{array}$ & Management (2) \\
\hline Traditional external stakeholders & Subcontractors / suppliers (2) & \\
\hline Enlarged external stakeholders & $\begin{array}{l}\text { Local NGOs (5) } \\
\text { Traditional chiefs from the urban area (2) } \\
\text { and the rural area (3) }\end{array}$ & \\
\hline Coordinating authorities & $\begin{array}{l}\text { Local authorities (4) } \\
\text { Institutions (4) }\end{array}$ & $\begin{array}{l}\text { Ministries (3) } \\
\text { Institutions (4) }\end{array}$ \\
\hline
\end{tabular}

\section{Definition and organization of sustainable development issues}

Stakeholder interviews in Niger were based on a semi-directive approach with two main questions: First: According to you, what are the impacts of, and your concerns related to, the mining activity? Second: How would you measure these impacts? Not surprisingly, a large spectrum of sustainability issues was mentioned by the participants, from the preservation of traditional ways of living, to health, through economic development, contributions to state revenue or water access and impacts on biodiversity. We organized these impacts in nine broad categories based on an analysis of all contributions and on international frameworks (Table 2).

\section{Step 2: Identifying "candidate" indicators}

The objective of this step was to define a first set of indicators that fit with the issues defined in Step 1 but also that address broader requirements for mining sites sustainability assessment. (For example, energy consumption, though a major issue for mining, was not mentioned by the stakeholders in our interviews). The question of the relevance of these indicators would then be tested through having them submitted to stakeholders' judgement. For this reason we speak of "candidate" indicators, which means indicators that are considered provisionally as pertinent, that are "up for consideration" as it were.

Three main sources of "candidate" indicators were available:

- Stakeholder' proposals;

- Indicators used by the Nigerian companies for their CSR reporting; 
- Indicators specific to the mining sector.

\section{Stakeholder proposals}

During the first phase of interviews, about fifteen indicators were proposed on various issues (health impact, company contributions to local communities, etc.). The main reason for this restricted number is the semi-directive approach used for the interviews, which aimed at giving full opportunities to participants for making proposals. For many of them, however, the concept of "measure" was difficult to understand.

The proposals obtained in this way are not always completely satisfying from a "scientific" standpoint, but they express real expectations from stakeholders. Therefore it was decided to keep them in situations where no real equivalent could be found in the other two types of indicator sources. For example, one stakeholder proposal was "Radiological impact of mining activity on employees". As Areva's reporting includes three indicators on this subject, the candidate indicator was not retained. Inversely, another proposal was "Local polygamy rate compared to the national rate" (miners who earn relatively high wages can marry more women than others). As no such indicator was found in the other sources, this proposal was adopted.

\section{Areva's CSR reporting}

Forty-eight indicators from Areva's CSR reporting were found to be suitable for both of Niger mining companies. However, these indicators cover only a limited range of domains: environmental aspects (impact, consumption, management) and internal social issues (H\&S, equity and formation) [22]. No indicator was proposed for measuring community or economic aspects. All the "candidate" indicators from this source were retained, for several reasons. First, it was hypothesised that testing them with stakeholders will enable companies to see their adequacy or limits "in the field". Second, data from these indicators should be easily recovered from companies, which is a crucial point in countries where data are difficult to obtain. And third, uranium mining generates specific issues that are not necessarily revealed in other mining-sector initiatives (such as radiological impacts).

\section{Mining sector indicators}

As mentioned earlier, there a now a great number of international studies that have developed sustainable development indicators for the mineral sector. From these, more than a thousand indicators were obtained and compiled in a database [23]. Several selection operations were necessary to get down to a "reasonable" number of indicators! First, all indicators whose scale was unsuitable (e.g. sectorial indicators), and those that were not relevant to the study (indicators very specific to another substance, to a geographic context, or to a life-cycle phase), or that were poorly defined (too vague or imprecise such as "Community dependency", "Mining activity as pollution source" or "Corruption") were eliminated. It was also decided to exclude all qualitative indicators that did not have a clear "observable" character; such indicators lead to a lack of transparency in data collection and do not facilitate comparisons between sites [24]. The last step was to assess the relevancy of the remaining indicators (about 400) with reference to the spectrum of performance 
issues identified in the first phase of our study. Indicators were rated from 1 (very relevant) to 3 (not relevant) for each issue.

In sum, a total of 127 indicators was obtained after reconciling all three sources; these indicators are more or less equally distributed across all nine issue categories (Table 2).

\begin{tabular}{|c|c|}
\hline Issue Category & $\begin{array}{l}\mathrm{Nb} \text {. of } \\
\text { indicators }\end{array}$ \\
\hline Economic and financial performances & 9 \\
\hline Redistribution of benefits & 6 \\
\hline Local community & 13 \\
\hline Employee health and safety & 18 \\
\hline Employment and equity & 13 \\
\hline Wages and working conditions & 12 \\
\hline Environmental management & 14 \\
\hline Resources and products management & 19 \\
\hline Environmental impacts & 16 \\
\hline
\end{tabular}

Table 2 - Number of indicators by issue category

\section{Step 3: Assessing the relevancy of potential indicators with stakeholders}

Assessing the relevancy of potential indicators was again based on a participatory process, involving the same stakeholder groups in Niger as during the first phase of issue definition. However, this time meetings were not individual but based on the focus-group technique, whose objective is to stimulate dialogue between participants in a small group on a specific theme, encouraged by a moderator [15]. To ensure that people could freely express themselves, the groups consisted of actors from the same stakeholder category. Fifteen meetings took place, engaging a total of 80 persons, $97 \%$ of whom were Nigerian. However, the balance across strakeholder types was not even: Two of the broad stakeholder categories - internal stakeholders (6 groups and 34 people) and coordinating authorities (6 groups and 30 people) - were relatively more strongly represented than the others.

Each focus group was asked to agree on a maximum of five indicators, deemed to be the most pertinent for each of the nine issue categories. They were free, however, to formulate new indicator proposals if this was felt to be necessary. This ceiling of five indicators, which some participants found frustrating, had the double objective of reducing the total number of indicators to obtain a workable data set (more or less homogeneously distributed amongst the nine categories) and of fostering dialogue between participants.

\section{Step 4: Selection of the final set of indicators}

Selection of the final set of indicators was based on the principle of "representative diversity" [16]. This aims at highlighting, as much as possible, the diversity of (1) issues and (2) viewpoints of the stakeholders, without drowning them in a majority opinion. The idea is that, where possible, 
deliberative procedures should attenuate contradictory opinions without eliminating them [25], providing the opportunity to all parties, even minorities, to be represented and thus to make them feel involved in the final result. In fact, this selection process of the final data set amounted to requiring the four categories of stakeholders to participate in a negotiation activity, with the objective of reaching an equilibrium between consensus and strong expressions of interest, while attempting to preserve the entire diversity of stakes.

With the objective of selecting 5 indicators by issue category, four rules were applied in a non-linear and non -exhaustive manner:

1- Search for and selection of indicators with a strong measure of consensus;

2- Search for and selection of indicators stressing strong expressions of interest of stakeholder groups;

3- Search for and selection of "compensation" indicators for the other stakeholders;

4- Search for and selection of indicators to favour a diversity of issues in case the other selection criteria arrive at a stalemate.

Figure 2 - Voting results by participants for each type of stakeholders in the category "Local community"

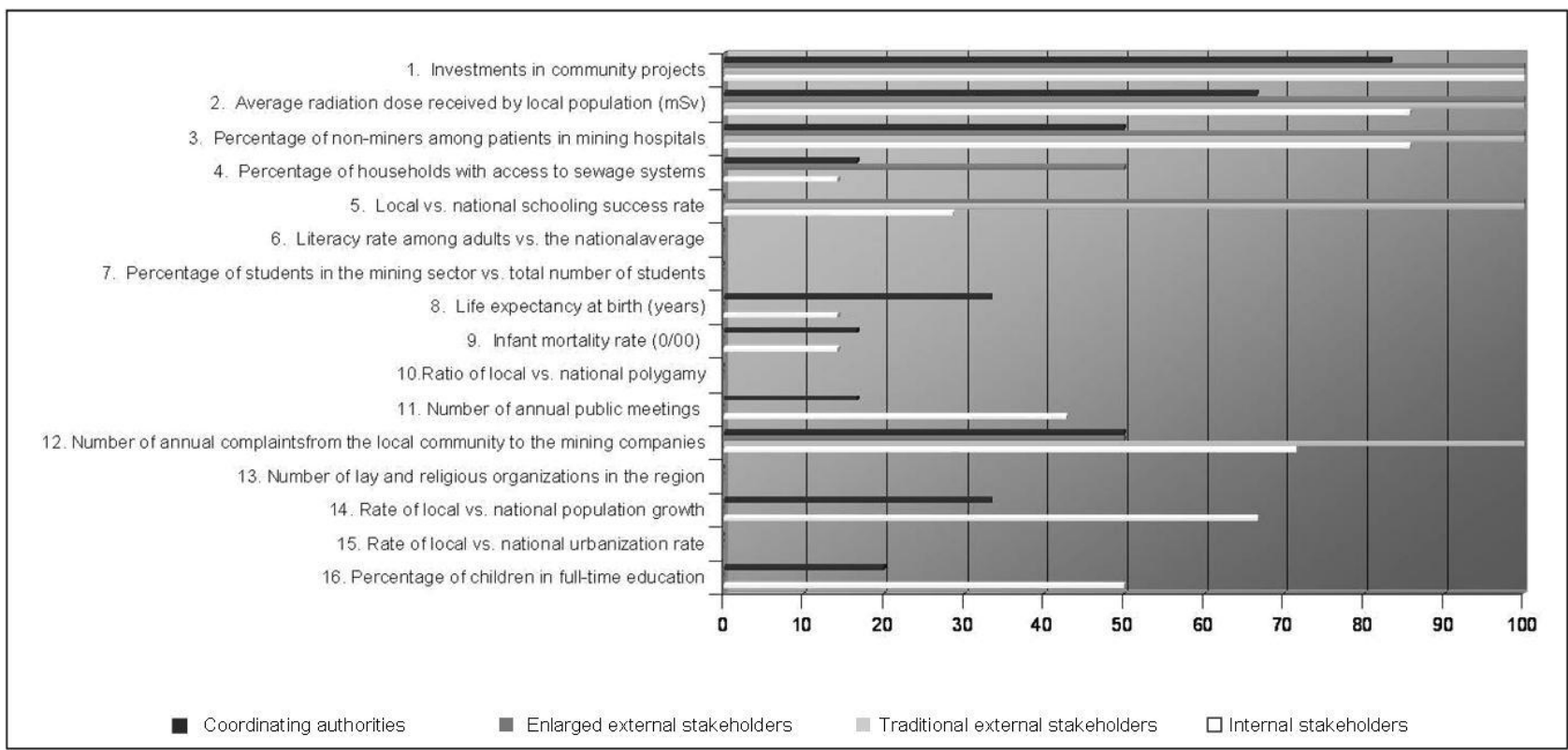

For illustration, take the example of the "Local community" issue category (Figure 2 and Table 3). Two indicators obtained a certain measure of consensus in the eyes of the four stakeholder groups. These were "Investment in community projects/turnover" and "Average radiation dose received by local population". A strong interest was expressed by external stakeholders for the indicator "Local vs. national schooling success rate". In compensation, the indicator that best answers the expectations of internal stakeholders and the coordinating authorities is "Percentage of non-miners among patients in mining hospitals". Finally, among the remaining indicators, the "Number of complaints from the local community to the mining companies" corresponds most to the expectations of all four groups, as well as highlighting another facet of the Local Community aspect. 
The five indicators that were retained are thus "Investment in community projects/turnover", "Average radiation dose received by local population", "Local vs. national schooling success rate", "Percentage of non-miners among patients in mining hospitals", and "Number of complaints from the local community to the mining companies".

Table 3 - Voting results by participants for each type of stakeholders in the category "Local community"

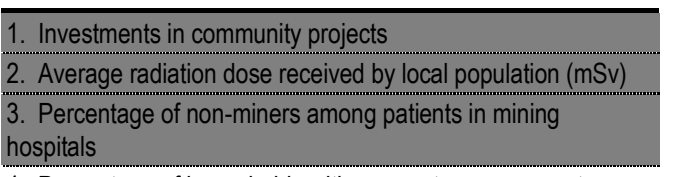

4. Percentage of households with access to sewage systems 5. Local vs. national schooling success rate

6. Literacy rate among adults vs. the nationalaverage

7. Percentage of students in the mining sector vs. total number of students

8. Life expectancy at birth (years)

10.Ratio of local vs. national polygamy

11. Number of annual public meetings

12. Number of annual complaintsfrom the local community to the mining companies

13. Number of lay and religious organizations in the region

14. Rate of local vs. national population growth

15. Rate of local vs. national urbanization rate

16. Percentage of children in full-time education

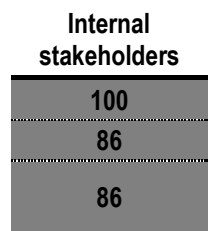

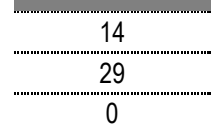

0

\begin{tabular}{|c|}
\hline 14 \\
\hline 14 \\
\hline 0 \\
\hline 43 \\
\hline
\end{tabular}

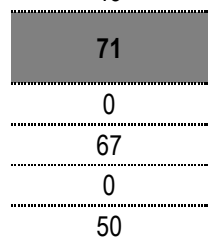

Traditional external stakeholders

\begin{tabular}{|c|}
\hline 100 \\
\hline 100 \\
\hline
\end{tabular}

100

\begin{tabular}{|c|}
\hline 0 \\
\hline 100 \\
\hline 0 \\
\hline 0 \\
\hline
\end{tabular}

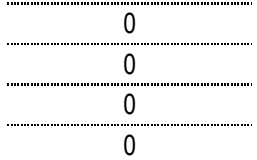

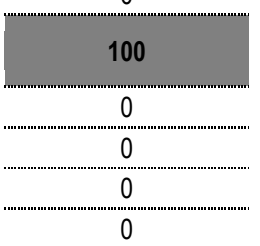

Coordinating authorities

\begin{tabular}{c|c}
\hline 100 \\
\hline 100 \\
\hline 100 \\
\hline 50 \\
\hline
\end{tabular}

50

\begin{tabular}{c}
100 \\
\hline 0
\end{tabular}$-\frac{17}{0}$

o

\begin{tabular}{|c|c|}
\hline 0 & 33 \\
\hline 0 & 17 \\
\hline 0 & 0 \\
\hline 0 & 17 \\
\hline 50 & 50 \\
\hline 0 & 0 \\
\hline 0 & 33 \\
\hline 0 & 0 \\
\hline 0 & 20 \\
\hline
\end{tabular}

Overall, at the end of this selection work, 45 indicators were retained, homogeneously distributed within the nine issue categories. A quick comparison between this approach and a selection based on majority opinion (viz. selecting the most popular indicators among all stakeholders groups) shows a $10 \%$ divergence in the results. Thus, most of the indicators that would be retained by the majority opinion approach could equally have been chosen in our "representative diversity" selection procedure. But, the application of diversity criteria has enriched the selection with coverage of more issues in a more varied way. For example, through the majority approach two indicators would have been retained for measuring water consumption in the issue category "Resources management". We chose only one and replaced the second by an indicator measuring the space used by mining, revealing a distinct concern of the enlarged external stakeholders group.

Among the 45 indicators selected in the final set, 35 were chosen by enlarged external stakeholders, 34 by the traditional external stakeholders, 34 by the internal stakeholders and the coordinating authorities. These figures show that an "equity" in the respect of diversity across viewpoints has been assured. 


\section{Conclusions}

This article has presented a novel approach for building sustainable development indicators, using the Arlit mines as case study. Our approach is based on the principle that a sustainability assessment should reveal the diversity of issues associated with mining and the diversity of stakeholders concerns in a structured way. For this, we have used a hybrid approach, combining top-down and bottom-up tools.

The final set of indicators retained in our case study reveals the strong complementarity of the two angles of attack. In the overall process, four main sources of "candidate" indicators have been identified by and/or submitted for consideration to stakeholders. These are:

- "Raw" stakeholders' propositions;

- Equivalents of stakeholders propositions from international initiatives;

- Indicators from international initiatives responding to stakeholders' expectations;

- Indicators from international initiatives that do not directly respond to stakeholders' expectations but judged as necessary for mining projects assessment.

Figure 3 shows that most of the indicators retained are located on the interface between top-down and bottom-up approaches. This result highlights the legitimacy of hybrid approaches.

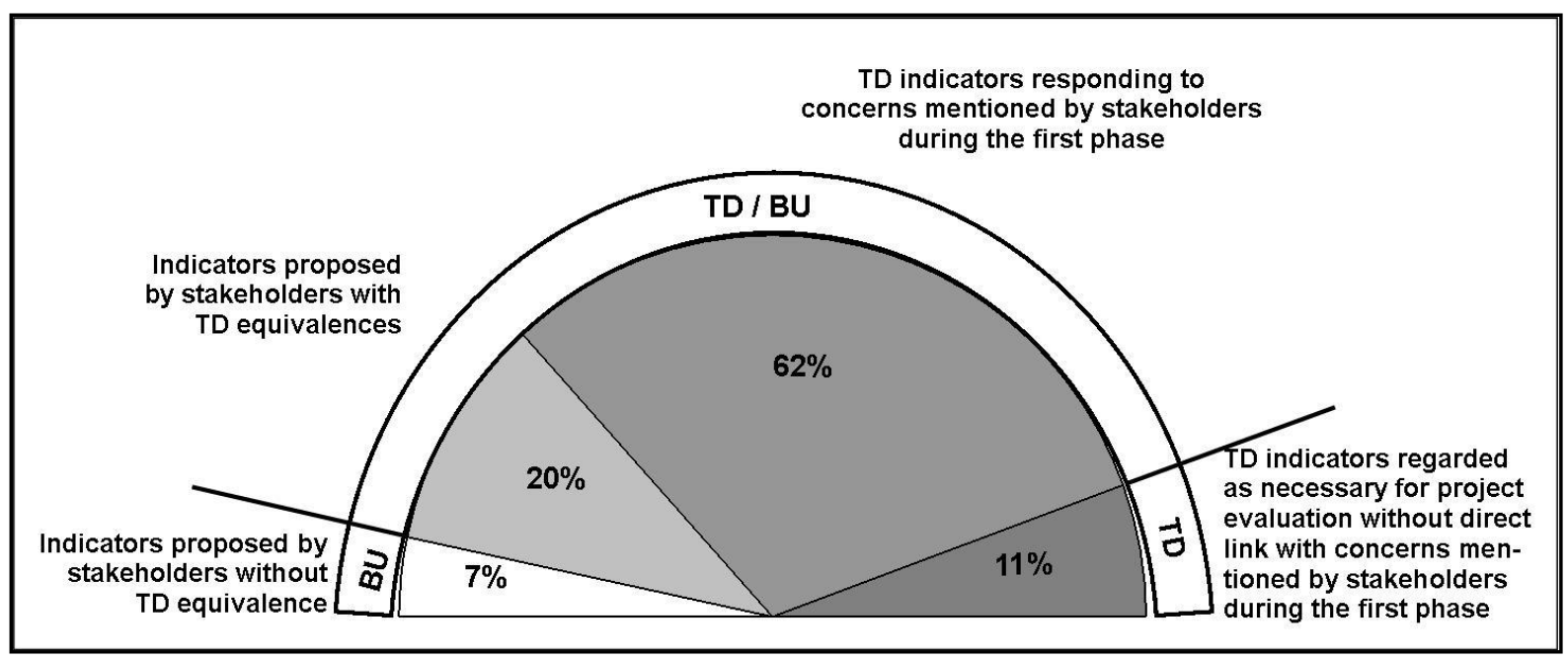

Figure 3 - Distribution of the final set of indicators according to their 'top-down' and 'bottom-up' origin

\section{Acknowledgements}

We wish to thank all participants in the meetings, as well as AREVA's Mining Business Unit, COMINAK, SOMAIIR and AREVA NIGER for their welcome and their logistic support on site. 


\section{References and notes}

1 Such as the Mining, Minerals and Sustainable Development initiative (see : www.iied.org/mmsd/) initiated by the industrial association, International Council for Mining and Minerals (ICMM), which also developed Principles for Sustainable Development (see: www.icmm.com). CSR reports are more numerous and complete every year. It also demonstrates the importance of sustainable development issues for mining companies.

2 See, notably, the campaign by Friends of the Earth against mining activities (www.foei.org/mining/), "Publish What You Pay" that urges extractive companies to be more transparent concerning their contributions to governments (www.publishwhatyoupay.org), or the associations group, Mines and Communities, that denounces local practices of mining sites (www.minesandcommunities.org).

3 In particular the Extractive Industry Review (http://www.eireview.org/), launched by the World Bank Group for enhancing good governance in extractive projects, or the Equator Principles (http://www.equator-principles.com/) that not only focus on the mining sector, but have been adopted by many international commercial banks to promote new social and environmental standards for financing projects that cost $\$ 50$ million or more.

4 World Bank (2004). Vers un nouvel Equilibre - Le Groupe de la Banque Mondiale et les Industries Extractives : le Rapport Final de la Revue des Industries Extractives - Projet de Réponse de la Direction du Groupe de la Banque Mondiale: $41 \mathrm{pp}$.

5 Chamaret, A., Récoché, G. \& O'Connor, M. (2005). Proposal for a top-down/bottom-up approach to build up indicators of sustainable development for use in the mining industry in Africa. In RWTH Aachen University - Virginia Tech University - Technical University of Crete (Ed.) Sustainable Development Indicators in the Minerals Industry. Aachen.

6 Global Reporting Initiative (2005). GRI Mining and Metals Sector Supplement Pilot Version 1.0 Incorporating an abridged version of the GRI 2002 Sustainability Reporting Guidelines. Amsterdam, Netherlands.

7 Azapagic, A. (2004). Developing a framework for sustainable development indicators for the mining and minerals industry. Journal of Cleaner Production, 12, pp. 639-662.

8 Warhurst, A. (2002). Environmental and Social Performance Indicators (ESPIs) in Minerals Development - Final Report to Department for International Development and MERN Institutional \& Industry Club of Sponsors - Consultation Draft. Warwick, UK, MERN - University of Warwick.

9 Ripmeester, W. (2003). Canada's Minerals and Metals Indicators (MMI) Initiative. In Agioutantis, Z. (Ed.) Sustainable Development Indicators in the Mineral Industries. Milos, Greece, Milos Conference Center - George Eliopoulos.

10 The Raw Materials Supply Group (2004). Sustainable Development Indicators for the EU NonEnergy Extractive Industry in 2001 - Final SDI report. UE.

11 Shields, D.J., Wagner, L.A. \& Van Zyl, D.J.A. (2003). Indicators of minerals systems productions to sustainability in the USA. In Agioutantis, Z. (Ed.) Sustainable Development Indicators in the Mineral Industries (SDIMI 2003). Milos Conference Center - George Eliopoulos. 
12 Mining, Minerals and Sustainable Development (MMSD) North America (2002). Seven Questions to Sustainability: How to Assess the Contribution of Mining and Minerals Activities. International Institute for Sustainable Development.

13 Miranda, M., Burris, P., Froy Bingcang, J., Shearman, P., Briones, J.O., La Vina, A. \& Menard, S. (2003). Mining and Critical Ecosystems: Mapping the risks. Washington D.C., The World Resources Institute.

14 Bouni, C. (1998). Sustainable development indicators: theory and methodology. Nature Sciences Sociétés, 6, 18-26.

${ }^{15}$ Faucheux, S. \& Nicolaï, I. (2004). La responsabilité sociétale dans la construction d'indicateurs : l'expérience de l'industrie européenne de l'aluminium. Nature Sciences Sociétés, 30-41.

16 O'Connor, M. \& Spangenberg, J. (2007, in press). A Methodology for CSR Reporting: Assuring a Representative Diversity of Indicators across Stakeholders, Scales, Sites and Performance Issues. Forthcoming in the Journal of Cleaner Production.

17 Nuclear Information Centre (2005). World Uranium Mining. Nuclear Issues Briefing Paper.

18 United Nations Development Programme (UNDP) (2005). Human Development Report 2005 International cooperation at a crossroads: Aid, trade and security in an unequal world. New York, US.

${ }^{19}$ Freeman, E. (1984). Strategic Management. A Stakeholder Approach. Boston: Pitman Press

20 Östensson, O. (2000). The Stakeholders: Interests and Objectives. In Otto, J. M. \& Cordes, J. A. (Eds.) Sustainable Development and the Future of Mineral Investment,. Paris, United Nations Environment Program (UNEP) and Metal Mining Agency of Japan (MMAJ).

21 Azapagic, A. (2004). Developing a framework for sustainable development indicators for the mining and minerals industry. Journal of Cleaner Production, 12, pp. 639-662.

22 Coupin, Y. \& Beutier, D. (2003. Corporate Reporting on Sustainability Performance: A New Challenge and a Learning Process. In World Nuclear Association (Ed.) World Nuclear Association Annual Symposium. London.

${ }^{23}$ Chamaret, A., Récoché, G. \& O'Connor, M. (2005). Proposal for a top-down/bottom-up approach to build up indicators of sustainable development for use in the mining industry in Africa. In RWTH Aachen University - Virginia Tech University - Technical University of Crete (Ed.) Sustainable Development Indicators in the Minerals Industry. Aachen.

24 Observatoire sur la Responsabilité Sociétale des Entreprises (ORSE) (2003). Analyse comparative d'indicateurs de développement durable. Paris, Observatoire des Stratégies Industrielles, direction générale de l'industrie, des technologies de l'information et des postes (DIGITIP) ministère de l'Économie, des Finances et de l'Industrie.

25 O'Connor, M. (2002), 'Social Costs and Sustainability', pp.181-202 in: Daniel H. Bromley and Jouni Paavola (eds., 2002), Economics, Ethics and Environmental Policy: Contested Choices, Edward Elgar, Cheltenham. 